\title{
THE SEC PROXY PROPOSAL RULE: THE CORPORATE GADFLY
}

\author{
Frank D. Emerson* and Franktin C. Latcham $\dagger$
}

$I^{2}$ I IS HARDIY CONCEIVABLE today that any large proportion of shareholders in one of our publicly held corporations could attend a stockholders' meeting. The participation by the shareholders in the affairs of their corporation is, therefore, effectively limited to their vote upon matters presented to them through the proxy machinery. Congress has delegated to the Securities and Exchange Commission the duty of regulating the solicitation of proxies, at least in respect to securities registered on a national exchange and certain others. ${ }^{1}$ The SEC has attempted through its proxy regulation ${ }^{2}$ to insure that anyone who solicits proxies, whether management or an outside group, must supply the security holder with adequate information so that he may exercise an informed judgment in voting his shares.

Any shareholder attending an annual meeting would, of course, want to receive complete information on a matter before voting on it. He might also want to offer proposals of his own for consideration by his fellow security holders. He is afforded such an opportunity in the proxy regulation through the proposal rule. ${ }^{3}$ Stated generally, the rule gives a security holder the privilege of obligating the management to include in the management's proxy statement his proposal if it is a "proper subject for action by the security holders"; and also, if the management opposes the proposal, a supporting statement of the proponent's reasons for making the proposal together with his name and address. The purpose, therefore, of this article is to evaluate the proposal rule, now designated $X-14 A-8$,

* Interpretative Attorney for the Cleveland Regional Office of the Securities and Exchange Commission; Lecturer in Law (Securities), Western Reserve University Law School.

† Associate Professor of Law, Western Reserve University Law School. The opinions expressed in this article, and in particular those offered in connection with the prospects suggested for the proxy proposal rule, are the writers', and not necessarily those of the Securities and Exchange Commission.

I See $\$ 14$ (a) of the Securities Exchange Act of 1934, 48 Stat. 895 (1934), 15 U.S.C.A. $\S 78 \mathrm{n}$ (a) (1951), $\S 12(\mathrm{e})$ of the Public Utility Holding Company Act, 49 Stat. 823 (1935), 15 U.S.C.A. $\$ 791$ (c) (1951), and $\$ 20$ (a) of the Investment Company Act, 54 Stat. 822 (1940), 15 U.S.C.A. $\$ \$ 80-\mathrm{a} 20$ (1951).

2 The SEC proxy rules, designated Regulation X-14, consists of Rules X-14A-1 through X-14A-9 and Schedule 14A, Items 1 through 21. See 17 Code Fed. Regs. $\$ \$ 240.14 a-240.14 a-9$.

3 The proxy proposal rule is Rule X-14A-8, formerly X-14A-7. 
from the standpoint of its operation during the four years 1948-1951, as indicated by a survey conducted by the writers, and on the basis of these results and other pertinent developments, to reflect as to the rule's prospects for stimulating more effective stockholder participation ${ }^{4}$ and fuller realization of the goal of "Stockholder Democracy."

\section{Commission and Court Opinions}

While a variety of questions arises in connection with the application of the proposal rule, ${ }^{6}$ the most perplexing problem is what constitutes a "proper subject for action by the security holders," and is, therefore, a "proper subject" for a proposal under X-14A-8. An early release was directed to this question. ${ }^{7}$ In a Commission statement preceding the opinion which was the occasion for the release, and also in the opinion itself, it was stated that a "proper subject" is one relating "directly to the affairs of the particular corporation," and concluded that proposals dealing with "general political, social, or economic matters" are not within the proposal rule..$^{8}$ The opinion also stated that, "speaking generally," it is the purpose of the rule to place security holders "in a position to present proposals regarding matters of concern to their fellow security holders as such, in the corporation, that is, matters relating to the affairs of the company concerned as are proper subjects for stockholders' action under the laws of the state under which it is organized." On these grounds proposals that (1) dividends paid shall not be subject to federal income tax where the income from which the dividends are paid has already been subject to cor-

4 See Emerson and Iatcham, SEC Proxy Regulation: Steps Toward More Effective Stockholder Participation, 59 Yale I.J. 635 (1950) and the writers' Further Insight Into More Effective Stockholder Participation: The Sparks-Withington Proxy Contest, 60 Yale L.J. 429 (1951). See also Friedman, SEC Regulation of Corporate Proxies, 63 Harv. L. Rev. 796 (1950).

s The SEC has stated that its proxy rules "are probably the most useful of all the disclosure devices established by our various acts and represent an effective contribution to corporate democracy." Report of the SEC, Proposal To Safeguard Investors in Unregistered Securities, H.R. Doc. No. 672, 79th Cong. 2d Sess. 18 (1946). The initial report has been supplemented by a second report, also transmitted to Congress. Exchange Act Release No. 4399 (Jan. 9, 1950).

- Among the questions that may arise are those relating to the standing of beneficial owners who are not record owners to submit proposals, what constitutes reasonable notice of intent to present a proposal, and the extent of the activities a proponent who does not file his own proxy statement may carry on without being deemed to have engaged in illegal solicitation, all discussed in Emerson and Latcham, op. cit. supra note 4, at 433-37. Other questions concern the right of management to omit proposals submitted in bad faith or for the purpose of achieving some ulterior objective unrelated to corporate affairs, considered in Emerson and Latcham, op. cit. supra note 4 , at 667-68.

7 Exchange Act Release No. 3638 (Jan. 3, 1945).

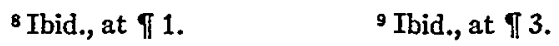


porate income tax, (2) the antitrust laws and their enforcement be revised, and (3) all future federal legislation providing for representation of workers and farmers apply equally to investors, were held improper subjects. ${ }^{10}$ The opinion's reference to state law pointed up an ambiguity in the rule, ${ }^{11}$ which itself became the subject of a court decision in the Transamerica case ${ }^{12}$ as well as indirectly the subject of a recent proposal for amendment of the rule. ${ }^{13}$

The proponent in the Transamerica case, John J. Gilbert, ${ }^{14}$ had in January, 1946, duly notified the Transamerica management of his intention to present four proposals at its April 25, 1946, annual meeting. The proposals submitted, according to the Commission's brief to the United States Supreme Court in opposition to Transamerica's petition for certiorari, were: (1) to have the independent public auditors of the company's books elected by the stockholders; (2) to amend the by-laws to eliminate their requirement that notice of any proposed alteration or amendment of the by-laws be contained in the notice of meeting: ${ }^{15}$ (3) to change the annual meeting place from Wilmington to San Francisco; and (4) to require that a post-meeting report be sent to all Transamerica stockholders. ${ }^{16}$

${ }^{10}$ Ibid., at $\uparrow 2$ and 4.

1I Loss, Securities Regulation 537 (1951).

${ }^{2}$ SEC v. Transamerica Corp., 16 F. 2d 511 (C.A. 3d, 1947), cert. denied, 332 U.S. 847 (1948).

13 One of the proposed amendments announced January 31, 1952, would incorporate into the rule provision for exclusion of proposals "primarily for the purpose of promoting general economic, political, racial, religious, social or similar causes," and made no reference to considerations based on state law, presumably because of the decision on that phase in the Transamerica case, ibid. Other proposed amendments of the proposed rule under consideration provide for amendment of the rules' reasonable notice of intent to present a proposal and its thirty day prima facie notice provisions so as to determine reasonableness by computing time from the date the prior proxy solicitation was made, rather than from the date of the prior security holders' meeting. A third amendment proposed would amend the 100 words of reason paragraph to provide that the reasons need only be in support of the proposal and that specific "reasons" need not necessarily be advanced. See Exchange Act Release No. 4668 (Jan. 31, 1952). The time for interested persons to comment to the Commission on these and other proposed amendments to the proxy rules was extended to April 30, 1952, Exchange Act Release No. 4679 (Feb. 27, 1952).

14 See infra p. 830.

${ }_{15}$ Gilbert made it clear in his communication to Transamerica that his purpose was not to prevent actual notice of such matters to the security holders, but to prevent management from exercising its asserted power to block action on security holders' proposals by the technical device of excluding their proposals from the notice of meeting. Brief for the Respondent (SEC) in opposition to Transamerica's unsuccessful petition for certiorari at 6.

16 Ibid., at 6-7. The 1st and 4th proposals were adopted by the management after the litigation without submitting them to the security holders. The $3 \mathrm{~d}$ was submitted and adopted as a by-law amendment. The $2 \mathrm{~d}$ was mooted by the circuit court's opinion and therefore withdrawn. 
When the management, in disregard of the Commission's advice, mailed out its proxy statement without setting forth the four proposals, ${ }^{17}$ the Commission sought injunctive relief in the United States District Court. ${ }^{18}$

While the district court adopted Transamerica's view that its "notice" by-law was valid under Delaware law, it held that there was nothing in Delaware law, or the company's charter, or by-laws, requiring notice of the auditor proposal, for the reason that it was in the form of a proposed recommendation or suggestion from the security holders to the management, and was not offered as a proposal to amend the by-laws. ${ }^{19}$ The Third Circuit, on the other hand, adopted the Commission's view as to inapplicability of the "notice" by-law as a ground for excluding any of the proposals. It reversed the district court, and ordered resolicitation, being of the opinion that the proposals had as their subjects, matters "in respect of which stockholders have the right to act under the General Corporation Law of Delaware." ${ }^{\prime 20}$

Although the Third Circuit also had "no doubt" that the proposal rule represented "a proper exercise of the authority conferred by Congress on the Commission," it left undrawn the precise line of authority between security holders and directors from the standpoint of the permissible scope of security holder proposals under the law of the state of incorporation.11 However, some conclusions may nevertheless be drawn and should be of assistance. Thus, if it is clear as a matter of state statutory or common law that a given subject matter is one exclusively for the directors, a proposal for amendment of the by-laws or code of regulations in the given area would appear to be barred..$^{22}$ Similarly, if the corporate charter or articles of incorporation, or the by-laws or regulations, specifically restrict a subject matter to director action, stockholder proposals in the area would be barred. However, a stockholder proposal that the charter or articles or by-laws or regulations be amended to permit stockholder action

${ }^{17}$ Gilbert's proposals were described in the proxy statement under the provisions of the Schedule 14A item relating to disclosure of other matters. However, Gilbert's words of reason were not included, not were security holders afforded an opportunity by the management's form of proxy to vote on the proposals. Tbid., at 7 .

18 SEC Litigation Release No. 339 (April 16, 1946).

${ }^{19}$ See SEC v. Transamerica Corp., 67 F. Supp. 326 (D. Del., 1946).

${ }^{20}$ SEC v. Transamerica Corp., 163 F. 2d 511, 518 (C.A. 3d, 1947). The case is discussed in a Note, Permissible Scope of Stockholder Proposals under SEC Proxy Rules, 57 Yale L.J. 874 (1948).

${ }^{21}$ Note, ibid., and see Note, Stockholder Participation in Corporate Affairs, 37 Va. L.R. 595 (1951).

${ }^{22}$ Loss, op. cit. supra note 11 , at 528. 
in the area would certainly be permissible. ${ }^{23}$ And, furthermore, if under state law the given subject matter is exclusively one for director action, a proposal that the security holders recommend or suggest that the directors consider, or actually take, a desired action would appear well within the permissible area of proper subject matters. ${ }^{24}$

It has been suggested that, if a security holder has drawn his proposal as a recommendation or suggestion for director consideration or action rather than as a by-law amendment, ${ }^{25}$ the rule of the Transamerica case, involving as it does the spirit of the parent Exchange Act and the intent of Congress in adopting it, designates as a "proper subject" for security holder action any matter, stated generally, which is "reasonably related to the business affairs or management of the company."26 However, this proposition raises the question of what proposals are to be regarded as "reasonably related to the business affairs or management of the company." Furthermore, aside from somewhat narrowing the proposal area to "business affairs or management," this suggestion is essentially a restatement of the proposal rule requirement of "a proper subject for action by security holders." But general definitions of this type are frequently not too helpful in solving specific fact problems. Consequently, the writers have surveyed all proposals carried in management proxy statements dur- . ing the four-year post-Transamerica period of 1948 through 1951 in an effort to determine what proposals have in practice been included in management's proxy statements as apparently "proper subjects."

${ }^{23}$ For an example of a security holder proposal that the by-laws be amended to restore by-law amendment powers to the security holders, see Montgomery Ward \& Co. 1950 proxy statement. The proposal it contained reads: "Resolved, that the stockholders of Montgomery Ward \& Co., Incorporated, recommend that the Board of Directors give consideration to amending the By-Laws-(or Articles of Incorporation) so that the shareholders shall have the power to make, alter, amend, or repeal the By-Laws of the Corporation." And cf. the 2nd Transamerica proposal, supra.

24 This position accords with the Commission's practice of permitting the proposal rule to be used as a means for the security holders, the owners of the enterprise, to make known to their elected representatives, the directors, their views regarding the company's affairs. Loss, op. cit. supra note 11 , at 539 .

${ }^{25}$ A significant concomitant of a recommendation or suggestion proposal is that it would ordinarily be deemed to have carried, if it received a mere plurality of the votes cast as opposed to a requisite majority of all shares outstanding. Thus the 1950 Sparks-Withington Co. proxy statement contained three proposals, one drawn as a proposed by-law amendment and the other two not so drawn. All three received approximately $53 \%$ of the vote cast but less than a majority of the shares outstanding. The proposed by-law amendment (for security holder election of auditors) failed, while the other two recommendatory or suggestion proposals were declared carried. Of course, recommendations or suggestions, even though carried, are not binding upon the directors, but they express, nonetheless, the views of the voting security holders.

${ }^{26}$ See Caplin, Proxies, Annual Meetings, and Corporate Democracy, 37 Va. L.R. 653, at 671 , and $672-78$ (1951). 


\section{Survey of 1948-1951 Proposals}

Before discussing the results of the survey of the four post-Transameri$c a$ years, a brief over-all comparison with the four pre-Transamerica years will be helpful. ${ }^{27}$ Of the 6,380 management proxy statements filed with the SEC in the pre-Transamerica period, only 91 or 1.4 per cent carried a security holder proposal, and they contained a total of 135 security holder proposals presented by 56 different proponents. ${ }^{28}$ In the post-Transameri$c a$ period, of the 6,755 management proxy statements filed, only 177 or 2.7 per cent contained such proposals, and they carried 286 proposals by 71 proponents. ${ }^{29}$ It is apparent, therefore, that the proposal rule itself has not operated generally as an instrument of harassment of companies subject to the proxy rules, but that there has been, on the other hand, some growth in use by security holders of the privilege it affords them.

Turning to the four years surveyed, ${ }^{30}$ it was found that the 177 manage-

${ }^{27}$ Since the proposal rule was not expressly codified, as such, until 1943, Exchange Act Release No. 3347 (Dec. 8, 1942), the four pre-Transamerica years of 1944 through 1947 and the four post-Transamerica years of 1948-1951 represent practically the entire period, or eight of the nine years, during which the rule has been in effect. For discussion of the treatment of proposals during the five year period 1935-1940, see Dean, Non-Compliance With Proxy Regulation-Effect on Ability of Corporation to Hold Valid Meeting, 24 Cornell L.Q. 483, 499-500 (1939). And see also Exchange Act Release No. 2376 at 3 (Jan. 12, 1940) for a predecessor of the proposal rule.

${ }^{28} 15$ SEC Annual Report 48-49 (1950):

\begin{tabular}{|c|c|c|c|c|c|}
\hline Item & 1944 & 1945 & 1946 & 1947 & Totals \\
\hline Proxy statements filed by management........ & 1523 & 1570 & 1664 & 1613 & 6380 \\
\hline $\begin{array}{l}\text { Number of management proxy statements con- } \\
\text { taining security holder proposals............. }\end{array}$ & $\begin{array}{c}20 \\
(1.3 \%)\end{array}$ & $\begin{array}{c}14 \\
(0.1 \%)\end{array}$ & (1.1\%) & 38 & $\begin{array}{r}91 \\
(1.4 \%)\end{array}$ \\
\hline $\begin{array}{l}\text { Number of security holder proposals contained in } \\
\text { management proxy statements............. }\end{array}$ & 38 & (2.1\%) & (2.0\%) & $\begin{array}{c}29 \\
(1.7 \%)\end{array}$ & 135 \\
\hline $\begin{array}{l}\text { Net number of security holders whose proposals } \\
\text { were so carried, each counted but once...... }\end{array}$ & (1.1\%) & $\begin{array}{c}17 \\
(1.0 \%)\end{array}$ & $(0.5 \stackrel{9}{\%})$ & $(0.8 \%)$ & $\begin{array}{r}56 \\
(0.8 \%)\end{array}$ \\
\hline
\end{tabular}

${ }^{29}$ Figures for 1948 and 1949 are from 16 SEC Annual Report 42 (1951), and 1950 and 1951 are based on the latter two years of the writers' four year survey:

\begin{tabular}{|c|c|c|c|c|c|}
\hline Item & 1948 & 1949 & 1950 & 1951 & Totals \\
\hline Proxy statements filed by management........ & 1648 & 1625 & 1713 & 1769 & 6755 \\
\hline $\begin{array}{l}\text { Number of management proxy statements con- } \\
\text { taining security holder proposals............. }\end{array}$ & $\stackrel{38}{38}$ & $\stackrel{43}{(2.6 \%)}$ & $\stackrel{57}{(3.3 \%)}$ & $(2.39$ & $\begin{array}{c}177 \\
(2.7 \%)\end{array}$ \\
\hline $\begin{array}{l}\text { Number of security holder proposals contained } \\
\text { in management proxy statements........... }\end{array}$ & $\begin{array}{c}57 \\
(3.4 \%)\end{array}$ & (4) & $\begin{array}{c}96 \\
(5.6 \%)\end{array}$ & $\begin{array}{c}64 \\
(3.6 \%)\end{array}$ & $\begin{array}{c}286 \\
(4.2 \%)\end{array}$ \\
\hline $\begin{array}{l}\text { Net number of security holders whose proposals } \\
\text { were so carried, each counted but once...... }\end{array}$ & $\begin{array}{c}18 \\
(1.1 \%)\end{array}$ & $\begin{array}{c}21 \\
(1.2 \%)\end{array}$ & $\begin{array}{c}17 \\
(1.0 \%)\end{array}$ & $(0.9 \%)$ & $\begin{array}{c}71 \\
(1.0 \%)\end{array}$ \\
\hline
\end{tabular}

${ }^{30}$ The method of surveying the 102 companies' proxy statements was: Between December 14 and 21,1951 , an individually typed form letter was mailed to each of the 102 company presidents. The letter, after advising of the undertaking of the survey, noted that specified proxy 
ment proxy statements containing 286 proposals involved 102 different companies, and that 10 of the 102 were among the 58 in the country with assets of more than one billion dollars. ${ }^{31}$ The companies involved include our largest and most influential corporations whose lawyers and management in large measure set the pattern of corporate and economic life in the United States. Moreover, the social implications of the proposal rule are in any event vast, for it affords a medium for molding corporate policy and practice toward social objectives much more rapidly than can be hoped for through legislation because of the traditional "lag" of the law. The difference is one of weeks, months, or a few years as compared to decades or generations.

\section{Subject Analysis}

Transamerica-type. A convenient starting point is the post-Transamerica experience of presentation in other proxy statements of the three original Transamerica proposals, (1) security holder selection of auditors, (2) place of holding security holder meetings, and (3) post-meeting reports to security holders of the proceedings had at the security holders meetings. These three proposal subjects accounted specifically for a total of 69 or virtually 25 per cent of the 286 proposals presented in the four year

statements of the company addressed were included among the management proxy statements of 102 companies which had carried a security holder proposal during the four years 1948-51. A request was then made for a copy of the proxy statements involved, a specification of the vote for and against the proposals, and comments regarding the proposal rule. Confidential treatment of comments, if requested, was assured. Of the 102 companies, 84 had furnished their proxy statements, in most instances with the votes for and against, and in some cases with comments, by January 24,1952 . On or about that date a follow-up letter was written to the remaining 18 companies advising of the per cent of responses and renewing the requests made over a month earlier, with the result that 10 more companies responded. The ultimate balance of the proxy statements ( 8 companies) was borrowed from a private individual (4 proxy statements) or purchased from the SEC at the 10 cent per page photocopy rate prescribed in Securities Act Rule 121 (4 proxy statements). Actually, due to the slowness of 10 of the last 18 companies in responding and the failure of 8 of them to respond at all, it was necessary in the interests of time to purchase a total of 26 proxy statements from the SEC, after having borrowed 17 from the private individual referred to.

${ }^{21}$ The ten companies with assets of one billion dollars or more in order of their size: American Telephone and Telegraph Co. (11.5 billion), Standard Oil Co. (N.J.) (4.1 billion), General Motors Corp. (3.4), U.S. Steel Corp. (2.8), Pennsylvania R. Co. (2.3), E. I. duPont de Nemours (1.9), Consolidated Edison Co. of N.Y., Inc. (1.6), Texas Co. (1.4), Bethlehem Steel Corp. (1.3), and Marine Midland Corp. (1.2). See New Corporate Giants Join Billion Dollar Club, Cleveland Press, p. 18, cols. 3 and 4 (June 13, 1951), reflecting the results of a United Press survey. On achievement of social and economic objectives through mandatory consultation of the representatives of the corporate giants with government see Fischer, The Lost Liberals, 194 Harper's Magazine 385 (1947), reprinted in a note: Are There Wider Responsibilities in Berle and Warren, Cases and Materials on the Law of Business Organization (Corporations) 1102-11 (1948). There is an insignificant discrepancy of one between the survey total of 176 management proxy statements carrying security holder proposals, and the supplemented official total of 177 , shown op. cit. supra note 29 due to the different manner of counting December filings covering January and February meetings. 
period, ${ }^{32}$ and another 24 or 8.3 per cent of the proposals dealt with closely kindred subjects varying but slightly from the three original Transamerica proposals. ${ }^{33}$ Fully one third of the 286 proposals were essentially of the Transamerica type.

Tabulated as kindred to the original Transamerica proposal for security holder election of auditors were those calling for the presence at security holder meetings of a representative of the auditing firm in order that security holders' questions from the floor might be answered, the conducting of a detailed rather than a general audit, and the selection of an auditing firm other than the one engaged by management. ${ }^{34}$ Similar to the Transamerica proposal for the holding of security holder meetings at a central, readily accessible city, rather than at the city where the statutory office was located, were proposals for regional meetings of security holders, rotation of the meeting place, full discussion at meetings, and the calling of a special meeting. ${ }^{35}$ Of the same general scope of the Transamerica proposal for post-meeting report were those made so as to facilitate preparation

${ }^{32}$ The break-down, with results of voting where furnished, is:

\begin{tabular}{|c|c|c|c|c|c|c|c|c|c|c|}
\hline \multirow{2}{*}{ Proposal Subject } & \multicolumn{2}{|c|}{ NUBCBER OP } & \multicolumn{3}{|c|}{ UNDER $3 \%$} & \multicolumn{5}{|c|}{$3 \%$ AND OVEZ } \\
\hline & $\begin{array}{l}\text { Proxy } \\
\text { Sts. }\end{array}$ & Cos. & To $1 \%$ & $1-2 \%$ & $2-3 \%$ & $3-5$ & $5-8$ & $8-10$ & $10-50$ & $50+$ \\
\hline $\begin{array}{l}\text { Selection of Auditors....... } \\
\text { Meeting Place........... } \\
\text { Post-Meeting Reports.... }\end{array}$ & $\begin{array}{r}9 \\
23 \\
37\end{array}$ & $\begin{array}{r}8 \\
13 \\
25\end{array}$ & $\begin{array}{l}0 \\
0 \\
1\end{array}$ & $\begin{array}{l}1 \\
1 \\
2\end{array}$ & $\begin{array}{l}0 \\
2 \\
3\end{array}$ & $\begin{array}{l}0 \\
4 \\
5\end{array}$ & $\frac{1}{2}$ & $\begin{array}{l}0 \\
1 \\
3\end{array}$ & $\begin{array}{l}2 \\
2 \\
6\end{array}$ & $\begin{array}{l}2 \\
0 \\
0\end{array}$ \\
\hline Totals............ & 69 & . 46 & 1 & 4 & 5 & 9 & 10 & 4 & 11 & 2 \\
\hline
\end{tabular}

${ }^{33}$ The detail, as to the kindred Transamerica proposals, with voting, where furnished is:

\begin{tabular}{|c|c|c|c|c|c|c|c|c|c|c|}
\hline \multirow{2}{*}{ Proposat SUBJEct } & \multicolumn{2}{|c|}{ NuBraer op } & \multicolumn{3}{|c|}{ UNDER 3\% } & \multicolumn{5}{|c|}{ 3\% AND OVER } \\
\hline & $\begin{array}{l}\text { Proxy } \\
\text { Sts. }\end{array}$ & Cos. & To $1 \%$ & $1-2$ & $2-3$ & $3-5$ & $5-8$ & $8-10$ & $10-50$ & $50 \%+$ \\
\hline $\begin{array}{l}\text { 1. Selection of Auditors } \\
\text { Answer questions.... } \\
\text { Detailed audit, and } \\
\text { other auditors..... }\end{array}$ & $\begin{array}{l}3 \\
4\end{array}$ & $\begin{array}{l}3 \\
4\end{array}$ & $\begin{array}{l}0 \\
0\end{array}$ & $\begin{array}{l}0 \\
0\end{array}$ & 1 & $\begin{array}{l}0 \\
0\end{array}$ & $\begin{array}{l}0 \\
0\end{array}$ & $\begin{array}{l}0 \\
0\end{array}$ & $\begin{array}{l}0 \\
0\end{array}$ & $\begin{array}{l}0 \\
0\end{array}$ \\
\hline 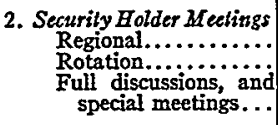 & $\begin{array}{l}9 \\
3 \\
2\end{array}$ & $\begin{array}{l}6 \\
3\end{array}$ & $\begin{array}{l}0 \\
0\end{array}$ & 2 & 1 & $\begin{array}{l}1 \\
0\end{array}$ & $\begin{array}{l}0 \\
2\end{array}$ & $\begin{array}{l}0 \\
0\end{array}$ & $\begin{array}{l}1 \\
0\end{array}$ & 1 \\
\hline $\begin{array}{l}\text { 3. Posh-Mreeting Refort } \\
\text { Stenographic record.. } \\
\text { Identify speakers.... }\end{array}$ & $\frac{1}{2}$ & $\frac{1}{2}$ & $\begin{array}{l}0 \\
0\end{array}$ & $\begin{array}{l}0 \\
0\end{array}$ & $\begin{array}{l}0 \\
0\end{array}$ & $\begin{array}{l}0 \\
1\end{array}$ & $\begin{array}{l}0 \\
1\end{array}$ & $\begin{array}{l}0 \\
0\end{array}$ & $\begin{array}{l}0 \\
0\end{array}$ & $\begin{array}{l}0 \\
0\end{array}$ \\
\hline Totals.............. & 24 & 21 & 1 & $\mathbf{0}$ & 4 & 2 & 3 & 0 & 1 & 1 \\
\hline
\end{tabular}

${ }^{34}$ Ibid., item \# 1.

35 Ibid., item \# 2. 
of a post-meeting report and that the post-meeting report furnished in the future identify the speakers at the security holder meeting..$^{36}$

Not revealed by the facts and figures stated is a clear trend, beginning even before the Transamerica case, toward security holder selection or approval of auditors, for the SEC has, in recent years, reported an ever increasing number of proxy statements carrying management proposals for security holder selection or approval of auditors. ${ }^{37}$ Moreover, two of the nine security holder proposals for security holder selection of auditors carried, but neither was opposed by the management. ${ }^{38}$ But management persists in resisting proposals ${ }^{39}$ not to meet in such places as Hoboken, ${ }^{40}$ Wilmington, ${ }^{41}$ Flemington, ${ }^{42}$ or Watertown, ${ }^{43}$ instead of such cities as New York City or Cleveland despite lampooning in the New Yorker, ${ }^{44}$ and criticism in the New York Tumes. ${ }^{45}$ The 37 post-meeting report proposals were opposed in virtually every instance, notwithstanding the fact that a long and impressive list of companies have for a number of years followed such a practice. ${ }^{46}$

Cumulative Voting. Cumulative voting, directors, dividends, and executive or employee remuneration accounted in the aggregate for another 150 , or fully 52 per cent of the 286 security holder proposals. ${ }^{47}$ The most

${ }^{36}$ Thid., item \# 3. See, e.g., Standard Oil Co. (N.J.) 1948 and 1950 stenographic transcript of its annual meetings. For current comment, with "gay and trenchant" cartoons, on annual meetings, see 45 Fortune Magazine at 108 (March 1952).

37 16 SEC Annual Report 42 (1951) shows 296 such management proposals in 1945; 304, 1946; 312, 1947; 365, 1948; and 381 in 1949.

${ }^{38}$ See Robt. Ries \& Co. 1949 proxy statement. The vote was $97 \%$ in favor of the security holder proposal. See also Trans-Lux Corp. 1951 proxy statement. Here the same proposal drew $98 \%$ of the shares voted.

39 See Gilbert, 12th Annual Report of Stockholders Activities at Corporation Meetings1951 at 3-12 (1952).

40 See U.S. Steel 1951 proxy statement.

il Coty, Inc., Coty Internat'l Corp. and Valspar Corp. 1951 proxy statements.

22 American Tobacco Company and Republic Steel Corp. 1951 proxy statements.

13 F. W. Woolworth Co. 1951 proxy statement.

${ }_{11}^{1}$ Logan, Profiles: Hoboken Must Go!, 27 The New Yorker at 34 (March 17, 1951).

${ }^{45}$ N.Y. Times (editorial page) p. 26, col. 4 (April 12, 1950).

16 Gilbert, op. cit. supra note 39, at 20-32. A substantial number of the companies surveyed who furnished information as to the vote for and against the security holder proposals carried in their proxy statements did so by supplying copies of their post-meeting reports.

17 The following table covering these proposals includes the results of voting, where furnished:

\begin{tabular}{|c|c|c|c|c|c|c|c|c|c|c|}
\hline \multirow{2}{*}{ Proposat SUBJEct } & \multicolumn{2}{|c|}{ NTMBER OF } & \multicolumn{3}{|c|}{ UNDER $3 \%$} & \multicolumn{5}{|c|}{$3 \%$ AND OVER } \\
\hline & $\begin{array}{l}\text { Proxy } \\
\text { Sts. }\end{array}$ & Cos. & To $1 \%$ & $1-2$ & $2-3$ & $3-5$ & $5-8$ & $8-10$ & $10-50$ & $50 \%+$ \\
\hline $\begin{array}{l}\text { 1. Cumulative Voting.... } \\
\text { 2. Directors............ } \\
\text { 3. Dividends........... } \\
\text { 4. Remuneration........ }\end{array}$ & $\begin{array}{l}58 \\
29 \\
16 \\
47\end{array}$ & $\begin{array}{l}28 \\
28 \\
15 \\
32\end{array}$ & $\begin{array}{l}0 \\
1 \\
0 \\
1\end{array}$ & $\begin{array}{l}0 \\
1 \\
0 \\
0\end{array}$ & $\begin{array}{l}3 \\
5 \\
0 \\
1\end{array}$ & $\begin{array}{l}8 \\
4 \\
2 \\
4\end{array}$ & $\begin{array}{r}18 \\
5 \\
2 \\
17\end{array}$ & $\begin{array}{r}7 \\
3 \\
1 \\
13\end{array}$ & $\begin{array}{r}17 \\
2 \\
7 \\
7\end{array}$ & $\begin{array}{l}0 \\
2 \\
0 \\
1\end{array}$ \\
\hline
\end{tabular}


frequently proffered of all the proposals submitted was cumulative voting, itself the subject of 58 or $20 \%$ of the 286 proposals surveyed. ${ }^{48}$ Typical of them and the supporting words of reason ordinarily used is the following:

- Resolved that at all elections of directors, the stockholders shall have the right of cumulative voting, that is to say each stockholder shall be entitled to as many votes as shall equal the number of votes which he would be entitled to cast for the election of directors with respect to his shares of stock, multiplied by the number of directors to be elected, and he may cast all of such votes for a single director or he may distribute them among the number to be voted for, or any two or more of them as he may see fit.

Reasons: Cumulative voting is mandatory in 19 states, as well as at all national banks. It is permissible in 16 additional states including Maryland in which Fairchild is incorporated. ${ }^{49}$

Although a recent study of cumulative voting concludes generally "that a powerful case can be made for management support of proposals to extend cumulative voting," ment. ${ }^{51}$ In many instances, a particularly persuasive argument made for proposing cumulative voting was that the company, for the purpose of electing directors, classified them into two or more panels with terms expiring in successive years, with the result that two or more years, depending on the number of classes or panels, would be required in order to un-

48 Ibid., item \# 1.

49 Fairchild Engine and Airplane Corp. 1951 proxy statement. While management is not required to afford the proponent more than 100 words in support of his proposal, there have been several recent instances of voluntary inclusion of more than 100 words. See 1949 Argus, Inc. (now Argus Cameras, Inc.) proxy statement (108 words); Air-Way Electric Appliance Corp. 1948 proxy statement (184 words); General Motors Corp. 1951 proxy statement (135 words); Kaiser-Frazer Corp. 1949 proxy statement (102 words); and Republic Steel Corp. 1950 proxy statement ( 130 words). Proponents of more than one proposal are entitled to at least 100 words per proposal irrespective of whether the additional proposals are submitted for inclusion in the same or different proxy statements. A generally similar English statute affords 1,000 words. See British Companies Act, 10 \& 11 Geo. VI, c. 47, § 3(1)(b) (as amended, 1947).

${ }^{50}$ Williams, Cumulative Voting For Directors 184 (1951). See also Young, The Case for Cumulative Voting, [1950] Wis. L. Rev. 49, Axley, The Case Against Cumulative Voting, [1950] Wis. L. Rev. 278, and Cole, Legal and Mathematical Aspects of Cumulative Voting, 2 S.C.L.Q. 225 (1950). •

51 Representative of the management opposing statements is the following: "After careful consideration your Board of Directors recommends to the stockholders that they vote against this proposal. A board of directors should manage the affairs of the corporation in the interest of all stockholders. A director elected only because of a cumulative voting provision represents an individual stockholder or a small group of stockholders. This would tend to produce a board composed of rival factions rather than one designed to obtain the best results of all stockholders. Unless contrary instructions are noted thereon, it is accordingly intended to vote all proxies against the amendment of the By-Laws of the Corporation to provide for cumulative voting in all elections of directors, in the event this matter is properly brought before the meeting." Fairchild Engine \& Airplane Corp. 1951 proxy statement. 
seat an incumbent majority ${ }^{52}$ It is not unprecedented, however, for management directors to support security holders' proposals for cumulative voting even though the majority of directors opposes..$^{53}$ The "stagger system"54 has also been attacked directly by proposals to elect all directors annually. Five proposals, involving five different companies, urged annual elections of all directors..$^{55}$

Directors. Proposals relating expressly to directors have involved a variety of matters. ${ }^{56}$ Seven of them called for women directors, four having been proposed by the Federation of Women Shareholders in American Business, Inc., and three by individual women. ${ }^{57}$ At American Radiator and Standard Sanitary, the women's shareholder group urged in 1950, in its 98 words of reason, that:

Larger proportion of our company's products go into the home or are used by women in a competitive market. Company research and development work should benefit by woman's angle. A qualified woman on our Board would give better representation to women's equity in our company, tend to increase investment appeal since more women than men are stockholders in many major companies. Asked to consider a woman for the Board by the Federation of Women Shareholders in American Business,

52 The so-called "stagger" system obtains, as indicated by their proxy statements for the indicated year, at the following companies and to whose managements proposals for cumulative voting were submitted: American Can Co. (1951), American Gas and Electric Co. (1951), American Radiator \& Standard Sanitary Corp. (1951), Bethlehem Steel Corp. (1951), Corn Products Refining Co. (1951), Internat'l Salt Co. (1950), Nat'l Biscuit Corp. (1951), Nat'l Dairy Products Corp. (1951), Phillips-Jones Co. (1950), Radio Corp. of America (1951), and United Stores Corp. (1951).

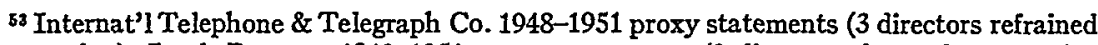
from voting), Jacob Ruppert 1949-1951 proxy statements (2 directors favored cumulative voting), and Western Union Telegraph Co. 1948-1951 proxy statements (1 director, who in a prior year had been a proponent, favored).

Apart from the proposal rule, Item 3(a) of Schedule 14A requires management to give in the proxy statement the name of any director who has informed the management in writing that he intends to oppose any action intended to be taken by management, and to indicate the action he intends to oppose. For an example of a 1951 proposal to restore cumulative voting after a 1950 voting of management stock in favor of abolishing cumulative voting and without soliciting other security holders proxy on the matter, see Coty, Inc. (1951) proxy statement. Coty did not furnish the results of voting, nor did Coty Internat'l.

54 See text at note 52 supra. See also as to cumulative voting, Gilbert, 12 th Annual Report of Stockholders Activities at Corporation Meetings-1951 at 57-65 (1952).

\$s See American Gas and Electric Co. 1951 proxy statement, Atlantic Refining Co. 1951, Follansbee Steel Corp. 1950, Internat'l Salt Co. 1950, and R. Hoe \& Co., Inc. 1950. Two of these proposals drew a 2 to $3 \%$ favorable vote, one 8 to $10 \%$, and a fourth, Follansbee, $18 \%$.

${ }^{56}$ For general tabulation of the voting on these proposals, see supra note 47 , item \# 2 .

${ }^{67}$ For F.W.S.A.B., Inc. proposals, see American Radiator \& Standard Sanitary Corp. 1950 and 1951 proxy statements, Alex. Smith \& Sons Carpet Co. 1950, and Borden Co. 1951. For such proposals by other women, see American Telephone \& Telegraph Co. 1951, and Bayuck Cigar, Inc. 1950 and 1951. 
Inc. at the last annual meeting, no action has been taken by our directors. Stockholders ask for more outside directors. ${ }^{58}$

To this type of argument the typical management reply was that, "apart from the questionable validity of the proposal, it is unnecessary because the by-laws already permit election of women as Directors, and it is unwise and unsound because qualification for the office of Director should rest upon competency, and not upon any discriminatory characteristic such as sex, or color, or race, or creed." ${ }^{\prime 59}$

Another recurring variety of proposal affecting directors was contained in seven proposals seeking to require stock ownership by directors or officers, at least 100 shares being called for in four instances. ${ }^{60}$ Still other proposals affecting directors provided for: abolishing the post of chairman of the board ${ }^{61}$ a preferred stock nominee, ${ }^{62}$ questioning at security holders' meetings of nominees, ${ }^{63}$ "'outside 'nominees'," 364 barring director's relatives from handling the company's publicity and advertising, ${ }^{65}$ and banning indemnification of directors. ${ }^{66}$

Doubtless the most far reaching of all the proposals pertaining to directors was contained in the Illinois Central R.Co. 1949 proxy statement. It suggested a procedure for stockholders to nominate by petition a slate of

58 American Radiator \& Standard Sanitary Corp. 1950 proxy statement. At A.T. \& T., the words of reason pointed out that millions of women are "telephone subscribers and telephone operators," that a member of the FCC is a woman, that Western Union and Nat'l Broadcasting Co. recently put women on their boards, and that the proposal "for a woman on our Board was 'seconded' by four men, including a union representative, at stockholders' annual meeting two years ago." American Telephone \& Telegraph Co. 1951 proxy statement. The Bayuck Cigar Co. proposal for a woman director made reference to "feminine prejudice against cigar smoking."

59 American Radiator \& Standard Sanitary Corp. 1950 proxy statement.

${ }^{60}$ American Beverage Corp. 1949 (annual and special meetings) proxy statements, American Gas \& Electric Co. 1951, and Universal Pictures, Inc. 1949. Ownership of 1000 and 2000 shares were called for in two other proposals, Bethlehem Steel Corp. 1949 (annual meeting) and Sparks-Withington Co. 1950. The other stipulated stock ownership equal to earnings for past three years, New England Electric System 1951. All but the latter drew more than 3\% of the shares voted, and the Sparks-Withington Co. proposal was declared carried with a $53 \%$ majority. A reason urged in support of the proposal at Bethlehem was, "Since owners take the brunt of any financial or social, or governmental reaction against the Corporation they should exercise a greater influence in forming its policies and directing the execution of same." Ibid.

51 Missouri-Kansas-Texas R. Co. 1951 proxy statement (4\% favorable vote).

62 Atlantic Gulf \& West Indies S.S. Lines 1950 and Pittsburgh Steel Co. 1949 proxy statements ( 1 and $14 \%$, respectively, favorable vote).

${ }^{63}$ A. Hollander \& Son, Inc. 1950, McCrory Stores Corp. 1950 (less than $2 \%$ favorable vote), and D. A. Schulte, Inc. 1950 proxy statements.

${ }^{64}$ Standard Oil Co. (N.J) 1950 proxy statement (over $2 \%$ favorable vote).

65 Willys-Overland Motors, Inc. 1949 (nearly 5\% favorable vote).

${ }^{66}$ Texas Co. 1948 (over 1\% favorable vote). 
opposition, or stockholder, nominees. The proposals were: nomination by signators owning of record 5,000 shares, inclusion in the management proxy statement of information such as required by the SEC as to nominees, with 100 words giving the nominees' qualifications, and opportunity to vote for the candidates by means of appropriate boxes to be carried in the management form of proxy. The supporting words of reason asserted that the proposal "seeks to give the common stockholder some effective power of initiative in the choice of directors without having to bear the whole expense of solicitation as individual candidates while management candidates have their solicitation expenses paid by the company." It was added that "[i]t seeks to provide an alternative to the one ticket type of election which has become characteristic of all too many large corporations." 67

Dividends. Dividends, notwithstanding a widely professed contrary theory as to stockholders' principal interests, were the subject of only sixteen proposals which were carried in the management proxy statements of fifteen different companies. ${ }^{68}$ Six of the proposals, made by the same proponent, were, with one exception, identical in providing that "the stockholders . . . recommend that the Board of Directors give consideration to reducing salaries of officers, executives, and directors who receive more than $\$ 25,000$ per year when the earnings of the company have been reduced or dividends have been reduced." "69 There were three other similar proposals by two other proponents relating to the dividend-salary policies of two other companies, one of which, made in connection with the passing of a dividend, was "[t]hat until a dividend of not less than $\$ 1.60$ per share per annum is declared by the corporation, the salaries of the President and Vice President shall be reduced to $\$ 40,000$ and $\$ 20,000$ per annum, respectively, and that the salaries of other officers of the Company be reduced proportionately until such time as such dividend is declared, and that these salaries shall not be increased unless the dividend of the stock-

67 The Commission in 1942 proposed a similar broadening of the proposal rule, Exchange Act Release No. 3347 at 2 (Dec. 18, 1942), but the Congressional inquiry followed and it was not adopted. Recently the suggestion was reiterated. See Caplin, op. cit. supra note 26 . The Illinois Central proposal received between 8 and $10 \%$ of the vote cast.

For a thoughtful article, with a provocative suggestion, concerning proxy contest expenses of opposition groups, see Friedman, Expenses of Corporate Proxy Contests, 51 Col. L.R. 951 (1951).

${ }^{68}$ Supra note 47 , item \# 3.

${ }^{69}$ The exception which referred only to dividends and not to earnings was the proposal carried in the proxy statement of the American Telephone and Telegraph Co., which has for years paid a $\$ 9.00$ dividend. For the other five proposals, see the following proxy statements: Gimbel Brothers, Inc. 1950; Montgomery Ward \& Co. 1950; Paramount Pictures Corp. 1950; 20th Century Fox Film Corp. 1950; and Loew's Inc. 1950. 
holder is also increased."70 The second of the dividend-salary proposals, also keyed to the passing of dividends, was that, if in any year the dividends on the capital stock of the corporation shall be suspended, and shall continue suspended for two dividend periods, the salaries of the major officers should be reduced to a maximum of 50 per cent of the salary then existing. ${ }^{71}$ Another dividend proposal called for relating dividends and payments to the management profit sharing bonus plan so that payments into the bonus fund would be made on the basis of 10 per cent of cash dividends paid to the common stockholders. ${ }^{72}$ Elsewhere it was proposed to relate dividends to incentive compensation and preferred stock sinking fund payments. ${ }^{73}$

The remaining five dividend proposals struck directly at dividend policy. ${ }^{74}$ One called for a special dividend of such funds as were available in the amount of $\$ 10$ per share. ${ }^{75}$ Another, pointing, inter alia, to earnings of approximately $\$ 90$ a share from 1941 through 1948 proposed that "it is the sense of this (security holders') meeting that the plowing back of further earnings is not warranted and the directors should give immediate consideration to the prompt resumption of dividend payments out of surplus." " $\mathrm{A}$ uniform basis of paying dividends has also been urged, the pro-

${ }^{70}$ The Brooklyn Union Gas Co. 1948 proxy statement.

7 The proposal further provided that the salary reductions should continue until such time as dividends should be resumed and continued for at least four dividend periods, it being understood specifically that salary "reinstatements" should be made at the end of the period, and begin to accrue at that time. See A. Hollander \& Son, Inc. 1949 proxy statement (votes not furnished). The third such proposal was for a $25 \%$ officer salary cut effective until common stockholders had received $\$ 1.25$ a quarter for 18 months. See Illinois Central R. Co. proxy statement (4.85\% favorable vote).

${ }^{72}$ Reynolds Metal Co. 1950 proxy statement. The proposal received a $16 \%$ favorable vote.

${ }^{73}$ The proposal requested that the directors amend the Incentive Compensation Plan to provide that no incentive compensation be payable until deduction had been made for all preferred dividends and sinking fund requirements and payment of not less than $\$ 1.00$ a share on common, Willys-Overland Motors, Inc. 1950 proxy statement. There was a more than $5 \%$ favorable vote on the proposal.

${ }^{74}$ See on stockholder actions directed at dividend policy, Ballantine, Corporations 550602 (1946).

${ }_{75}$ The proposal likewise sought reduction of capitalization or share stated value. The words of reason made reference to the directors expressed "intention of purchasing a wholly unrelated business" as an indication of "unneeded funds . . . available for distribution to stockholders," "a balance of $\$ 12,780,296$ of funds previously authorized for retirement of shares," and possible "violation of the provisions of the internal revenue laws against accumulations" with resultant "severe penalties" if the proposed distribution were not made. See Pullman Incorporated 1949 proxy statement. Slightly more than a 5\% vote for the proposal was recorded.

${ }^{76}$ Illinois Central R. Co. 1949 proxy statement. For references to two other proposals carried in the same proxy statement, see text and note at note 67 supra and text and note at note 71 supra. 
posals being "[t]hat . . . dividends shall be paid on the Common Stock in an amount equal to one half of the Net Profits for each year, provided the Net Current Assets exceed the Net Current Liabilities by the ratio of four [dollars of] Current Assets to one [of] Current Liabilities. "'77 In the KaiserFrazer 1949 proxy statement there was a security holder proposal advocating a policy that a substantial portion of the net earnings, when, as, and if earned, after December 31, 1948 be used to pay regular quarterly dividends. ${ }^{78} \mathrm{~A}$ most interesting proposal, because submitted by a corporate proponent, the Graham-Newman Corporation of 120 Wall Street, a registered management, open-end, non-diversified investment company, stated, "Resolved that the stockholders of New Amsterdam Casualty Co. disapprove the dividend action of the Board of Directors as inadequate." In the Graham-Newman supporting words of reason, the New Amsterdam directors' $\$ 1$ dividend was described as "unduly niggardly."79

Remuneration. Although salaries were not sought to be reached directly by security holder proposals, except by means of suggestions for reductions in periods of reduced dividends, ${ }^{80}$ executive bonuses and other contingent additional remuneration, and executive retirement plans were the subject of a wide range of proposals, numbering in all $45(15 \%$ of the 286 proposals) and involving 21 companies. Eight of these proposals, six of which were made by the same proponent, ${ }^{81}$ were directed at five companies, one of whom, Bethlehem Steel Corporation, was the recipient of the same proposal in each of the four years surveyed. The proposal was a "request that the executives who are entitled to Special Incentive Compensation under Article $\mathrm{X}$ of the Amended Certificate of Incorporation of the Corporation resume the practice of waiving payments of certain amounts, as in 1945 and in certain prior years during World War II." 82 In the 1948 supporting statement, the proponent

77 See American Hide and Leather Co. 1948 proxy statement. The purpose of the proponent's provision for a 4 to 1 ratio of current assets to current liabilities was, of course, to allow management adequate working capital. $20 \%$ of the shares voted were for the proposal.

78 The words of reason made reference to earnings of $\$ 4$ and $\$ 2$ a share in 1947 and 1948, overcoming of initial losses, and more than adequate earned surplus, working capital, and cash positions at December 31, 1948. It was also said, "The Company spends huge sums on advertising to create goodwill-it pays banks their interest. But how about the stockholders, the owners of the business? Isn't their goodwill important?" There was a $21 \%$ favorable vote.

79 Graham-Newman also asserted that "average earnings justify a \$2 [100\% larger] dividend, giving us a standard and appropriate return of 4\%." See New Amsterdam Casualty Company 1948 proxy statement. The vote in favor of the proposal was $29 \%$ of the vote cast.

80 See supra pp. 819 to 820 .

${ }^{81}$ See infra pp. 830 to 832 . See note 47 , item \# 4 supra, for tabulation of results of voting on remuneration proposals.

82 Bethlehem Steel Corp. 1948 proxy statement. 
asserted that executive compensation had increased by $\$ 727,631$ over the previous years "to $\$ 2,209,744$," and that "yet even as late as 1947 management has deemed it wiser to pay stockholders no extra cash dividends as money is needed for other corporate purposes." References were also made to the receipts of Bethlehem's and U.S. Steel's board chairmen and presidents, it being asserted that Bethlehem's "Grace received \$293,279-similar occupant at U.S. Steel $\$ 106,700$. Bethlehem's President received $\$ 239,399$ vs. $\$ 154,800$ at U.S." $" 83$

At DuPont and General Motors the same proponents sought to hold bonuses to 100 per cent of base pay or salary. The proposal to GM carried a further suggested bonus ceiling of $\$ 120,000$ per annum, reference being made in the words of reason to the GM president's $1949 \$ 201,000$ salary and $\$ 308,021$ bonus, and the DiuPont president's total compensation of $\$ 427,333$, and that of seven of his vice presidents each in excess of $\$ 250,000 .^{84}$

Other proposals have been made to place ceilings on executive bonuses, the most notable relating to the American Tobacco Co. ${ }^{85}$ One 1948 proposal sought to achieve the objective by a ceiling on the number of American Tobacco senior vice presidents, to be set at five, and a companion proposal urging an incentive compensation ceiling of $\$ 200,000$ for the president and $\$ 150,000$ for senior vice presidents. The supporting reasons said that "levels of executive compensation are far too high even after allowing for current taxation." It compared American Tobacco's directors' and of-

${ }^{83}$ The Bethlehem management footnoted the comparisons made by the proponent to the effect that it "does not assume any responsibility for the accuracy of the statements with regard to United States Steel Corporation contained in this paragraph," but did not undertake to contradict them. While the proponent, of course, stated his position in not in excess of 100 words, amounting here to approximately 7 lines in each of the 4 years, Bethlehem in 1948 took approximately two pages to explain its opposition to the proposal. Comparable prolixity will be found in their 1949, 1950, and 1951 opposition statements. Bethlehem held its 1948-1951 security holders' meetings at Wilmington, Delaware.

${ }^{84}$ See E. I. duPont de Nemours \& Co. 1950 and General Motors Corp. 1951 proxy statements. These proposals received less than $1 \%$ and $4.5 \%$, respectively, of the votes cast. The other two instances of proposals directed at executive bonuses were found in the Air-Way Electric Appliance Corp. and American Steel Foundries 1948 proxy statements. The proposal to the Air-Way security holders, which drew a $9.2 \%$ vote, was that in entering into employment contracts, the directors should "limit contingent compensation to percentages of increases in net annual profits, after taxes, above the then calendar year," and that fixed compensation in excess of $\$ 30,000$ per annum should be "submitted for approval by a majority of eligible common stock votes." The similar proposal at American Steel Foundries was that the directors "not vote or approve any pension, bonus, dole, gratuity, option, insurance, or separation pay" if "compensation for the previous year was Five Thousand Dollars or more, without consent of two-thirds of all classes of stock eligible to vote."

${ }^{85}$ See Rogers v. Guaranty Trust Co., 288 U.S. 123, 133 et seq. (1933), regarding solicitation of proxies to approve stock subscription plan of American Tobacco Co. without disclosure of its "tremendous" advantages for the management. 
ficers' compensation of " $\$ 2,073,822.76$ (rise of $\$ 1,168,392.51$ over prior year)" with Liggett and Myers' $\$ 650,478.02$, and pointed to this, and the respective presidents' compensation of " $\$ 285,669.45$ " and " $\$ 86,079.67$ !!!", in the context of American Tobacco's then preparations "to issue more stock to provide money for additional working capital.",86

Another proponent sought a $\$ 10,000$ ceiling on remuneration other than salary. ${ }^{87}$ Three other proposals affecting remuneration other than salary, urged that the practice of continuing salaries of deceased officers or employees to the end of the fiscal year and paying them to their family, extend only to the laboring employees or office staff not otherwise compensated by insurance or pensions. ${ }^{88}$ The three proposals further urged that a "full revelation be made to stockholders of all salaries and other remuneration of officers and directors received from any other company as a result of their employment," 89 and that directors' action in purporting to sell 22,500 shares of company stock to its president and two vice presidents for their 10 year promissory notes be treated as "excessive and unreasonable compensation . . . be rescinded."

Another type of recurring remuneration proposal dealt with ceilings for benefits to be paid under management retirement plans, and was involved in 17 proposals, carried in 12 different companies' proxy statements. Two proponents lead numerically in this area, one $e^{91}$ having submitted eight, and the other ${ }^{92}$ seven, of the 17 proposals. One of the two proponents urged adoption of a resolution that stockholders "request" that the "Directors

80 The situation indicated by the 1949 and 1950 American Tobacco Co. proxy statements is not sufficiently different to warrant specific treatment of the similar proposals carried in the management proxy statements for those years. The votes for these proposals were: 1948, slightly under $8 \% ; 1949,6 \% ; 1950,9 \%$. In 1951 , shortly prior to the American Tobacco Co. annual meeting at Flemington, the management agreed to substantial conformity with the proposals, and accordingly the proponent also agreed to abstain from resubmitting them at the 1951 annual meeting, Gilbert, 12th Annual Report of Stockholders Activities at Corporate Meetings-1951 at 39 (1952), and only resubmitted his proposal for cumulative voting, American Tobacco Co. 1951 proxy statement.

87 R. H. Macy \& Co., Inc. 1948 proxy statement.

${ }^{88}$ The proponent had previously been a director of the company for fifteen years. See A. Hollander \& Son, Inc. 1949 proxy statement. Although twice requested, the company did not furnish the results of the voting.

${ }^{89}$ The proponent was a former employee. See Cities Service Co. 1948 proxy statement. The proposal, one of four by the same proponent, received slightly over $3 \%$ of the vote cast.

${ }^{90}$ The management in two proposals sought security holder ratification of the executive stock sales and a direction not to sue the three executives, in addition to opposing the proposal (see Hawaiian Pineapple Co., Ltd. 1951 proxy statement). The security holder's proposal drew a $13.5 \%$ favorable vote, and the management proposals received $84.2 \%$ and $84.3 \%$. For the trend to management submission of such matters to security holders, see 16 SEC Annual Report 41-42 (1951), and Caplin, op. cit. supra note 26, at 673-74.

${ }^{21}$ See infra p. 830 et seq.

${ }^{22}$ See infra p. 830 et seq. 
consider and act upon a proposal to limit the amount of retirement benefits of officers ... which result from direct payments or contributions of the Company to a sum not in excess of $\$ 25,000$ except with respect to any officer whose rights under any retirement plan are now vested." In support he stated that two former officials received $\$ 71,577$ and $\$ 63,151$, and that his proposal "would insure that . . . high officials who retire on pension will be limited to a top of $\$ 25,000$ excluding the amount of their own contributions." ${ }^{93}$ The other of the two proponents sought to limit retirement benefits received by members of management to figures substantially lower than $\$ 25,000$, amounting in six instances to $\$ 10,000$ per year and in the seventh to $\$ 12,000$ per year. ${ }^{94}$ Other proposals in the same subject area called for payment of retirement costs by management participants, ${ }^{95}$ security holder approval of increases in management retirement benefits, ${ }^{96}$ and publicity in the annual report of a motion picture producer regarding retiring executives and actors whose compensation was more than $\$ 500$ per week ( $\$ 26,000$ per year). ${ }^{97}$

Rank and file employee retirement benefits have also been the subject of six proposals, all made by two unions of telephone company employees. Four of them were, in effect, for elimination of provisions that reduced the company pension by one-half of the benefits received under federal social security provisions. ${ }^{98}$ One of the two unions, the United Telephone organ-

${ }^{93}$ See American Can Co. 1951 proxy statement (slightly over $2 \%$ favorable vote), and also its 1950 proxy statement (slightly over 4\%), American Telephone \& Telegraph Co. 1950 and 1951 proxy statements (9.6\% and 9.3\% favorable), and Bethlehem Steel Corp. 1948, 1949 (annual and special meeting), and 1951 proxy statements (1948, vote of $12 \%$; 1949, slightly over $10 \%$ and $7 \%$, respectively; and 1951 , slightly over $7 \%$ ). See also Sparks-Withington Co. 1950 proxy statement, Proposal \# 2.

${ }^{94}$ R. H. Macy \& Co., Inc. 1948 and 1949 proxy statements (slightly over 8 and $10 \%$ votes for), Loew's, Inc. 1950 (14\%), Paramount Pictures Corp. 1950 (9\%), Standard Oil Co. (N.J.) 1950 (slightly over 3\%), 20th Century Fox Film Corp. 1950 (11\%), and U.S. Steel Corp. 1950 (special meeting) $\$ 12,000$ limitation (4\%).

${ }_{95}$ American Telephone \& Telegraph Co. 1950 proxy statement ( $7.2 \%$ for), R. H. Macy \& Co. 1948 and 1949 (slightly over $8 \%$ and 9\%, respectively), U.S. Steel Corp. 1950 (special meeting) (6\%). More specifically, the proposal made by the proponents of the proposals, referred to in note 94 supra, was that persons who receive more than $\$ 20,000$ per year pay $20 \%$ of pension plan costs if they desire to participate in its benefits.

${ }^{96}$ Johns-Manville Corp. 1950 (4.2\%) and U.S. Steel Corp. 1950 (special meeting) (6\%). Both of these proposals were made by the Federation of Women Shareholders in American Business, Inc. A similar proposal was for security holder approval of material changes in management retirement plans. See Consolidated Edison Co. 1950 proxy statement (9\%).

${ }^{97}$ 20th Century Fox Film Corp. 1951 proxy statement (93\%, carried and was not opposed by management). See also as to executive pensions, Gilbert, 12th Annual Report of Stockholders Activities at Corporation Meetings-1951 at 43 (1952).

98 American Telephone \& Telegraph Co. 1948 through 1951 proxy statements, all of which received from 5 to $8 \%$ of the votes cast. The proponents were, in 1948-50, the United Telephone Organization and, in 1951, the Alliance of Independent Telephone Unions. 
ization, also twice proposed an increase in employee minimum pension benefits from $\$ 50$ to $\$ 100$ per month. ${ }^{99}$

Securities Transactions. Securities transactions were the subject of nine proposals, three of which sought pre-emptive rights for security holders. ${ }^{100}$ Two of the proposals sought pre-emptive rights for common stockholders in all issues of new common or securities convertible into common, ${ }^{101}$ while the third specifically reached only new common as such. ${ }^{102}$ Another proposal affecting securities called for reduction of capital stock by means of a management call for tenders to the company..$^{103}$

Investments. The investment aspects of portfolio securities were the subject of another proposal in which the proponent urged that no further funds be spent for the purchase of corporate securities, except securities of corporations engaged in the utility business. ${ }^{104} \mathrm{~A}$ security holder of a registered investment company proposed that a $\$ 100,000$ ceiling be placed on the sum to be paid an affiliated corporation's investment management, research, statistical, and advisory service contract, and also that security holders be permitted to buy additional shares without paying the $8 \frac{1}{2}$ per cent sales load..$^{105}$ Elsewhere it was proposed that the directors sell to the security holders or distribute to them the proceeds from the sale of approximately $\$ 20,000,000$ worth of gas and electric utility company stocks owned by the company and representing holdings in six different companies. ${ }^{106}$ Perhaps the most interesting of the proposals relating to securities, and certainly the most vigorously supported and contested,

99 American Telephone \& Telegraph Co. 1948 and 1949 proxy statements (both received from 5 to $8 \%$ of the vote cast). For a recent injunction action against a labor organization which solicited proxies without having first filed a proxy statement, see SEC v. Local 291 of the Utility Workers of America, SEC Litigation Release No. 700 (Dec. 19, 1951).

${ }^{100}$ As to pre-emptive rights, see Ballantine, Corporations 487-93 (1946).

101 Internat'l Mineral \& Chemical Corp. and Meritt-Chapman \& Scott Corp. (special meeting held Jan. 15, 1952) 1951 proxy statements. These proposals received a 6 and $7 \%$ favorable vote, respectively.

${ }^{102}$ American Gas \& Electric Co. 1951 proxy statement. A 6.68\% favorable vote was cast.

${ }^{103}$ In her words of reason the proponent stated her purpose was to force management to perform the will of the stockholders, recalling that "in 1948, stockholders directed the use of $\$ 15,000,000$ for retirement of capital stock" and that "[o]nly a small portion was used." She added that "management has since indicated that it proposed using this money for other purposes." See Pullman Incorporated 1949 proxy statement and note 75 supra. The proposal received a $3.6 \%$ favorable vote.

104 Internat'l Utilities Corp. 1949 proxy statement. There was a 13\% favorable vote.

${ }_{105}$ American Business Shares, Inc. 1950 proxy statement, Proposal B and C, each of which drew approximately $7 \%$ of the vote cast.

106 United Gas Improvement Co. 1951 proxy statement. Approximately $23 \%$ of the shares voted were cast in favor of the proposal. 
was one to engage a designated appraisal or engineering firm to value the common stock of a recently acquired company and to adjust its carrying value to conform to the appraised value. ${ }^{107}$

Reports to Security Holders. Reports to security holders were the subject of twenty-one other proposals, seven relating to financial statements contained in annual reports, twelve to dissemination of quarterly comparative income statements of specified content, and two to semi-annual reports. Five proposals pertaining to two companies called for comparative balance sheets and income statements, ${ }^{108}$ and the other two asked that funds received from subsidiaries be specified ${ }^{109}$ and that reserves for inventory not exceed 50 per cent of the value of the inventory as of the last quarter. ${ }^{110}$ The seventeen quarterly report proposals were especially well received, for of the fifteen as to which results were obtained, four received from 10 to 15 per cent, ${ }^{111}$ and three, one of which carried, ${ }^{112}$ drew 88, 92, and 98 per cent favorable vote, respectively. ${ }^{113}$ Both of the proposals for semi-annual reports were submitted to the same company, and they suggested the company include "customary financial data," comment by the company president, and a summary or post-meeting report on the proceedings at the annual meeting. ${ }^{114}$

Investigation.Investigation was specifically ${ }^{115}$ requested in two proposals. One, was for examination of books and records of account and consultation with management and other security holders "for the purpose of considering various matters affecting the welfare of this Company and, in particular, its stockholders, including the possibility

${ }^{107}$ The words of reason spoke of a carrying figure of $\$ 896,750$ as compared with the stock's book value of $\$ 20,000$. Reference was also made to 1947 earnings by the acquired company of $\$ 305.51$. See Universal Laboratories 1948 (special meeting) proxy statement (vote not furnished).

${ }^{108}$ See American Beverage Corp. 1948 and 1949 (special meeting) and Overseas Securities Co., Inc. 1948, 1949 and 1950 proxy statements. While no data were furnished as to the vote on the American Beverage proposals, the similar Overseas proposals drew 6,6 , and $2 \%$, respectively.

${ }^{109}$ R. H. Macy \& Co., Inc. 1948 proxy statement. This won a $5 \%$ favorable vote.

${ }^{110}$ American Hide and Leather Co. 1948 proxy statement. A $19 \%$ favorable vote was received.

11 American Hide and Leather Co., ibid., Basic Refractories, Inc., Nachman Corp., and Rice-Stix, Inc. 1948 proxy statements.

112 Pittsburgh Steel Co. 1949 proxy statement.

${ }^{113}$ See Birsboro Steel Foundy \& Machine Co. and Elastic Stop Nut Corp. of America 1948 proxy statements.

114 Guatanomo Sugar Co. 1950 and 1951 proxy statements relating to January 1951 and 1952 annual meetings. In 1951 there was a $7.2 \%$ and this year a $4.3 \%$ favorable vote.

115 See text and note at note 107. 
of retiring part of the capital stock ${ }^{116}$ of the company and or maintenance of current dividends ${ }^{117}$ in the amount of full current earnings so long as any part of approximately $\$ 12,028,382$ net profits of the total proceeds of approximately $\$ 21,278,382$ from the sale of "a wholly owned subsidiary company remains."118 The other proposal for investigation covered (1) advisability of disseminating to stockholders condensed quarterly or semi-annual financials, (2) scrutiny of the services rendered by and compensation paid to a vice-president and his son, (3) study of the business and other connections of company officers and the former export manager with six business enterprises in which one or more of them was interested, (4) surveying of the company's dealer relationships and its operations generally, as compared to competitors, (5) review of the necessity for constructing a new office building within three blocks of an existing one only partially occupied, and (6) ascertaining whether investment advisers and brokers were reluctant to encourage investment in the company's common stock. ${ }^{119}$

Litigation. Three proposals pertained to pending or suggested litigation. One called for the company to print and send to each stockholder a copy of a statement, to be furnished by the proponent, regarding his charges against directors who were seeking re-election, of alleged mismanagement, which charges were included in a stockholders' suit the proponent had brought against six of the directors. ${ }^{120}$ The other two litigation proposals attempted to cause the company to sue its board chairman and also a former holder of its bonds to recover losses alleged to have been incurred by the company through the purchase from the bond holder of his bonds at a price substantially higher than prevailed in the open market. ${ }^{121}$ The same proponent, in a second proposal, asked that the company also sue its board chairman to recover money alleged

${ }^{116}$ See text and note at note 103. ${ }^{117}$ See supra p. 819 et seq.

${ }^{118}$ Allied Mills, Inc. 1948 proxy statement. The proposal received a $6 \%$ favorable vote.

${ }^{119}$ Sparks-Withington Co. 1950 proxy statement. This proposal drew $53.5 \%$ of the shares voted, and was declared carried.

${ }^{120}$ The proposal also sought to postpone the election of directors from the annual meeting scheduled for November 16, 1949 to February 17, 1950. The proponents statement would have constituted a "request ... not to execute ... a proxy," and therefore a solicitation within the meaning of $X-14 A-1$, with the result that the proponent was required to file his own proxy statement in order to be in a position to cause it to be sent to stockholders of the company. While the prononent filed a proxy statement and also solicited proxies, he withdrew his proposal before it was put to a vote. See Argus, Inc. (now Argus Cameras, Inc.) 1949 proxy statement.

${ }^{121}$ The words of reason stated that a suit instituted to recover the alleged loss had been dropped because of the expense involved, and pointed out the Statute of Limitations would bar action if suit was not begun in 1951. Missouri-Kansas-Texas R. Co. 1951 proxy statement. There was a $4 \%$ favorable vote for the proposal. 
to have been lost to the company through the chairman's "negligence or connivance" in failing to deposit promptly for collection a check given the company by the same bond holder in payment of a judgment obtained against the bond holder for "illegal gains" in the purchase and sale of the company's securities. ${ }^{122}$

Miscellaneous. There remain three miscellaneous proposals, one for a bylaw amendment restoring to the stockholders the right to make, alter, amend, or repeal the company's by-laws. ${ }^{123}$ The second, directed to use of company personnel, quarters, and services, was that the Federation of Railway Progress, of which the company board chairman was a founder, should not be permitted to use company personnel and facilities, and that the company withdraw its membership in the Federation, since it was also a member of the Association of American Railroads. ${ }^{124}$ The other sought reimbursement of stockholders of the company's bankrupt predecessor for losses they sustained, allegedly because of the sale of their stock at a time when the predecessor was not furnishing its security holders adequate information. ${ }^{125}$

As has been seen, some of the proposals were quite novel. And while others were not, many of them, for example, cumulative voting and abolition of the stagger system, because they are not operative in a substantial number of our largest corporations, continue to evolke interest. In any event, subject matters of the proposals were such that they serve to vindicate faith in stockholder democracy and rejection of the asserted fear that the proposal rule would provide a field day for crack-pot ideas.

\section{Results Analysis}

Results of the voting for and against the 286 proposals made during the four years 1948-1951 were furnished with respect to 232 or $81 \%$ of the proposals, ${ }^{126}$ and disclosed that only 7 or $2.3 \%$ of the proposals carried. Of the

122 The proposal also provided that counsel nominated by the Katy Stockholders Protective Committee be employed by the company to aid in the proposed suit. Ibid. This proposal also received a $4 \%$ favorable vote.

${ }^{123}$ Montgomery Ward \& Co. 1950 proxy statement. See text and note at note 23 supra.

124 Chesapeake and Ohio Ry. Co. 1948 proxy statement. The vote for the proposal was $6 \%$ of the shares voted.

${ }^{125}$ In his words of reason the proponent stated he had been a director of the predecessor from 1929 through 1934, serving as the Merrill Lynch \& Co. nominee. McCrory Stores Corp. 1950 proxy statement. The proposal received less than $1 \%$ of the vote cast.

126 While the proxy statements surveyed, as previously stated, are obtainable from the SEC, the results of the voting for and against the proposals were not required to be reported to any agency, and therefore are not publicly available, except as furnished to the writers. However, the SEC recently announced a proposed amendment to its periodic report form, Form 
seven, five either were not opposed, were favored, or were not the subject of any recommendations by the managements involved. ${ }^{127}$ Only two proposals, one for officer stock ownership and the other for investigation, and both submitted at the same time by the same proponent to the same company, Sparks-Withington Co., carried over management opposition. ${ }^{128}$ Moreover, the successful proponent filed his own proxy statement, and solicited proxies from the Sparks-Withington security holders in support of his proposals and his slate of nominees for directorships. Thus the Sparks-Withington proxy contest, the first occasion on which a "grass roots" committee, or a small stockholder's committee, of an "industrial" company listed on the New York Stock Exchange has been able to prevail over management in a proxy contest for election of a majority of the directors, ${ }^{129}$ re-emerges as the only instance shown by the survey when security holder proposals won over management opposition. By the same token, the Sparks-Withington contest revealed the only known use of proposals to support a contest for a majority of directorships.

Of the 229 proposals voted upon, ${ }^{130} 195$ or $85 \%$ received more than $3 \%$ of votes cast as required in order to be eligible for resubmission the next year. ${ }^{131}$ From time to time it has been suggested by the American Society

8-K, which would require, inter alia, reporting to the SEC of the vote for and against each matter voted upon at security holder meetings. See Exchange Act Release No. 4686 (March 17, 1952).

${ }^{127}$ American Airlines, Inc. 1950 (regional meetings, 90\%), Pittsburgh Steel Co. 1949 (quarterly financial reports, 98\%), Robert Ries \& Co. 1949 (security holder approval of auditor and auditor representatives present at meetings, 97\%), Trans-Lux Corp. 1951 (security holder election of auditor and respresentative present at meetings, $98 \%$ ), and 20th Century Fox Film Corp. 1951 (publicity in annual report of salaries of retiring executives and actors drawing more than $\$ 26,000$ per year, $93 \%$ ).

Since X-14A-8(b) requires inclusion of the 100 words of reason and identifying data only if management "opposes" the proposal, it would seem advisable to consider amendment of the rule to require inclusion of the 100 words, and also the identifying data regarding the proponent, unless management undertakes to vote for the proposal.

${ }^{128}$ The two proposals that carried, both recommendations or suggestions in form, received 53.6 and $53.5 \%$. However, another proposal by the same proponent, drawn as a by-law amendment, received $52.5 \%$ of the vote cast but failed because it did not obtain a majority of the shares outstanding.

${ }^{129}$ Emerson and Latcham, op. cit. supra note 4, at 430.

${ }^{130}$ Three of the 232 proposals as to which results were furnished were withdrawn or not presented by the proponents.

131

\begin{tabular}{c|c|c|c|c|c|c|c}
\hline \multicolumn{3}{c|}{ UNDER 3\% } & \multicolumn{5}{c}{ 3\% AND OVER } \\
\hline To $1 \%$ & 1 to $2 \%$ & 2 to $3 \%$ & 3 to $5 \%$ & 5 to $8 \%$ & 8 to $10 \%$ & $10-50 \%$ & $50 \%+$ \\
\hline 5 & 11 & 18 & 36 & 70 & 29 & 50 & 10 \\
\hline
\end{tabular}

See $X-14 A-8$ (c) (3) for the $3 \%$ or more requirement for resubmission. 
of Corporate Secretaries, Inc. that the $3 \%$ requirement be raised to 5 or $8 \%$. Since $30 \%$ of the 229 proposals received less than $5 \%$ of the shares voted and $60 \%$ received less than $8 \%$, it is apparent that such amendments to the proposal rule would have the result, if not the purpose, of substantially restricting the right to make proposals and would therefore impair considerably the effectiveness of the rule. ${ }^{132}$ It has also been suggested by the Society that an amendment should be adopted to require as a condition to resubmission that a proposal make progress, apparently, i.e. that in a succeeding year it receive an increasingly larger favorable vote. At the outset it is extremely doubtful whether progress may be defined mathematically. And even so, popularity is not to be confused with progress. In addition, there is the circumstance that security trading is going on continuously with the result that shareholders inevitably come and go, thus further increasing the problems of security holder communication and education. The safest approach would therefore appear to be to keep the resubmission restriction low, namely at 3\%, especially since the subject analysis has indicated that the proposals, though controversial, almost invariably have had intrinsic substance. ${ }^{133}$ Moreover, despite the failures to carry, the subjects presented by means of proposals have very often been adopted subsequently by opposing managements. ${ }^{134}$

\section{Proponent Analysis}

While the 286 proposals encompassed by the survey were made by fifty different proponents, forty-five of the proponents made only $27 \%$ of the proposals, and two brothers, Lewis D. and John J. Gilbert, ${ }^{135}$ submitted 137 or $47 \%$ of them. It is therefore understandable that Lewis Gilbert has been referred to, inter alia, as "The Talking Stockholder," "The Country's Most Celebrated Minority Stockholder,"136 "The Stockholders' Sir

132 Ibid.

${ }^{133}$ The survey disclosed no substantial physical burden on proxy statements as a result of the inclusion of proposals and supporting 100 words of reason, unusual length being the result of space taken by the management to oppose the proposals. Moreover, only 10 or $5.6 \%$ of the 176 proxy statements covered by the survey contained more than three proposals, and the average, as has been stated, was 1.5 proposals per proxy statement surveyed.

${ }^{134}$ See, e.g., Gilbert, 12th Annual Report of Stockholders Activities at Corporation Meetings-1951 (1952), and see also reports for prior years.

${ }^{135}$ Gilbert, ibid. See also the recurring activities of Clarence H. Venner as plaintiff in derivative suits, particularly in Venner v. American Telephone \& Telegraph Co., 181 N.Y.S 45, 110 Misc. 118 (1920). Venner v. Chicago City Ry. Co., 258 Ill. 523, 101 N.E. 949 (1913), Venner v. Great Northern R. Co., 209 U.S. 24 (1908), and Venner v. Southern Pac. Co., 279 Fed. 832 (1922).

136 Bainbridge, Profiles: The Talking Stockholder, 24 New Yorker at 40 (Dec. 11, 1948) and at 33 (Dec. 18, 1948). 
Galahad," "The Conscience of American Big Business," and he is perhaps, therefore, entitled to share with the proposal rule itself the title "The Corporate Gadfly."137

Gilbert, having inherited a portfolio of securities, attended his first security holders meeting in 1933. He was "horrified" at the proceedings, including the fact that, as he rose to ask a question, a company officer sitting in the back of the room made a motion to adjourn, which was immediately seconded and passed. In the succeeding years, Gilbert, described as "a bachelor of independent means and temperament," has made his sole occupation, aside from military service, the attendance of annual meetings. ${ }^{138}$ His activities have been conceded by many corporation executives to be constructive and worthwhile. ${ }^{139}$

Although he does not request proxies, Gilbert is willing to be entrusted with the forms of proxy sent out by management, and undertakes to vote them, if asked, with the result that he is deemed to be engaging in the solicitation of proxies within the meaning of X-14A-1. Consequently, he files a proxy statement with the SEC each January listing his and his brother's holdings in the companies whose security holder meetings they propose to attend during the ensuing year. ${ }^{140}$ His 1952 proxy statement indicates security ownership in 118 companies ${ }^{141}$ ranging from 5 to 324 , (averaging 36) shares. ${ }^{142}$ His objectives include questioning of corporate officials, accessible meeting places, use of the proposal rule, inspection of proxy ballots, availability of stockholders' letters by placing them on the meeting table, post-meeting reports, director stock ownership of at least 100 shares, pre-emptive rights, cumulative voting, and auditor election or approval by security holders. ${ }^{143}$ In general, his proposals have fared about

${ }^{137}$ Gilbert, Sour First Annual Meeting, 1 Investor at 26 (April 1950). See also Gilbert, Management and the Public Stockholder, 28 Harv. Bus. Rev. 73 (July 1950).

138 Op. cit. supra note 136 , at 40 and ibid.

${ }^{139} \mathrm{Op}$. cit. supra note 136 , at $46-47$.

140 See Gilber: 1952 proxy statement.

141 During 1951 Gilbert made 33 proposals.

142 Op. cit. supra note 140. John J. Gilbert, the proponent in the Transamerica case, op. cit. supra note 12, then owned but 17 of its shares. It may also be noted that American Telephone \& Telegraph Co. 1951, Texas Co. 1948, and U.S. Steel Corp. 1949, proxy statements carried proposals by the Alliance of Independent Telephone Unions, an individual, and the Federation of Women Shareholders in American Business, Inc. respectively, each of whom owned but one share of the company involved.

${ }^{143}$ Gilbert 1951 proxy statement, and see supra p. 813 et seq. 
the same as those of other proponents. ${ }^{144}$ Four other proponents, it may be noted, made a total of 70 or 24 per cent of the 286 proposals. ${ }^{145}$

\section{Proposals of a Political, Social, Economic, Religious, Racial, or Other Similar Nature}

An interesting facet of the problem of what constitutes "a proper subject for action by security holders" is presented by occasional stockholder proposals covering political, social, or economic issues. The Commission has formally ruled that proposals raising questions of a "general political, social or economic nature" are outside the ambit of proper stockholder action. ${ }^{146}$ This ruling was recently considered in a case in which a stockholder in the Greyhound Corporation requested management to include in its proxy statement for stockholder consideration "A Recommendation that Management Consider the Advisability of Abolishing the Segregated Seating System in the South." 147 The management refused to include the proposal in its proxy statement, and so advised the stockholder and the Commission. In an informal ruling signed by an Assistant Director, Division of Corporation Finance, the Commission agreed with management's

144

\begin{tabular}{c|c|c|c|c|c|c|c|c|c}
\hline & \multicolumn{3}{|c|}{ UNDER 3\% } & \multicolumn{5}{|c|}{$3 \%$ AND OVER } \\
\cline { 2 - 7 } & To 1\% & $1-2 \%$ & $2-3 \%$ & $3-5 \%$ & $5-8 \%$ & $8-10 \%$ & $10-50 \%$ & $50 \%+$ & CARRIED \\
\hline Gilbert.... & 2 & 5 & 9 & 14 & 35 & 15 & 17 & 1 & 2 \\
\hline
\end{tabular}

The relatively few proponents (7) who also filed their own proxy statements and thus solicited in behalf of their proposals obtained generally, of course, the better results. See Hawaiian Pineapple Co., Ltd. 1951 proxy statement (13.5\% favorable vote), Kaiser-Frazer Corp. 1949 (21\%), New Amsterdam Casualty Co. 1948 (29\%), Reynolds Metal Co. 1950 (16\%), SparksWithington Co. 1950 (3 proposals-52.5, 53.6, and 53.5\%), United Gas Improvement Co. 1951 (23\%), and Universal Laboratories, Inc. 1948 (vote not furnished).

145 The other four principal proponents were Luigi Criscuolo, 14 proposals, James Fuller, 27 , and Maurice Geller, 10, none of whom made any proposals in 1951, and the Federation of Women Shareholders in American Business, Inc., 19, all but one made in 1950 and 1951. See Women of Steel Give the Top Brass a Hard Time, 28 Iife Magazine at 46 (March 13, 1950) and Logan, Profiles: Hoboken Must Go! 27 The New Yorker at 34 (March 17, 1951).

Other notable proponents included an Illinois Court of Appeals judge (Minn. and St. Louis Ry. Co. 1950 proxy statement-for cumulative voting, $10.6 \%$ favorable vote), the GrahamNewman Corp. (New Amsterdam Casualty Co. 1948 proxy statement-increase dividend, $29 \%$ favorable vote), and two labor unions (American Telephone and Telegraph Co. 1948-51 proxy statements-increase employee pension maximum, each 5 to $8 \%$ favorable vote).

${ }^{148}$ Securities Exchange Act Release No. 3638 (Jan. 3, 1945). See also Exchange Act Release No. 4668 (Jan. 31, 1952) entitled Notice of Proposals to Amend Proxy Rules, in which the Commission proposes to amend paragraph (c) of Rule X-14A-8 to permit management to omit a proposal, "[i]f it clearly appears that the proposal is submitted ... primarily for the purpose of promoting general economic, political, racial, religious, social or similar causes."

${ }^{147}$ Peck v. Greyhound Corp., 97 F. Supp. 679 (S.D.N.Y., 1951). 
action. ${ }^{148}$ The stockholder thereupon brought an action in the federal district court to enjoin management from soliciting proxies, alleging that management's refusal to include his proposal in its proxy statement amounted to a violation of Section 14(a) of the Exchange Act and Regulation X-14.

After filing the action, plaintiff made a motion for a preliminary injunction which the court denied. In its opinion, the court decided the issue substantially on the procedural ground that plaintiff had not exhausted his administrative remedies. The court had before it as an exhibit the Assistant Director's letter advising of the Commission's informal ruling, and the court felt reluctant to hold contrary to the Commission's interpretation of its own regulation, especially where plaintiff had not perfected his administrative appeal.

The position of the Commission, as indicated in its informal ruling, was that management had the right to refuse to accept the proposal because it was of a "general" political, economic or social nature, and, therefore within the prohibition of the earlier, formal release. Furthermore, there is an indication from the informal ruling that the stockholder was not acting for the best interests of the company, but that he wished to utilize the proposal to promote propaganda interests of his own.

Of course, the Commission's position is unassailable if the proponent was not acting in good faith, that is, if he were prompted by considerations of a purely personal or special nature, rather than considerations relating to the best or common interests of the security holders of the corporation. The Commission's second ground for upholding the rejection, that is, that the proposal dealt with issues of a general political and social nature, is perhaps justified from the wording of the proposal. It was not limited to segregated seating on the corporation's buses alone. But what if a good faith proposal were limited to the corporation's policy of segregated seating on its own interstate buses? It would not then be "general" in nature. Certainly such a policy consideration is a "proper subject for action by security holders,"149 especially if the proposal were cast merely in the form of a recommendation or suggestion.

${ }_{148}$ Exhibit 7, filed in Peck v. Greyhound Corp., ibid., which is a letter dated March 8, 1951, signed by the Assistant Director, Division of Corporation Finance and addressed to the secretary of Greyhound Corp. For a reference to the Greyhound proponent, James Peck, in another context see 56 Time Magazine at 28 (July 17, 1950). See also SEC brief filed in Peck v. SEC, C.A. 2d, Case No. 22,289 (April 7, 1952) (not reported).

${ }^{149}$ See supra p. 808. On the civil liberties and constitutional aspects of segregated seating, see Henderson v. United States, 339 U.S. 816 (1950), but cf. second report of the ICC on further hearing of the case, four Commissioners dissenting (Feb. 4, 1952); Briggs v. Elliott, 342 U.S. 350 (1952) and 342 U.S. 931 (1952). 
The Commission has recently proposed to codify its previously expressed policies so as to preclude proposals designed primarily to promote "general economic, political, racial, religious, social, or other similar causes." 150 In light of the Greyhound case, it is interesting to speculate about the prospects under the proposal rule for some general and specific proposals which might be reached by the suggested amendment.

For example, a proposal that a food manufacturer reinstate a performer on its radio program who had been accused of communistic leanings would appear specific enough, although perhaps of a political nature, to constitute a proper subject. On the other hand, a proposal to support vigorous enforcement of the McCarran Act would seem to involve a general political subject.

Again, a proposal not to seek any further certificates of necessity permitting accelerated depreciation of defense facilities because of the loss of income tax deductions in future years, while economic in nature, should be adequately specific and not contravene the prohibition against general economic proposals. However, a proposal for support of the single tax program would seem to fall in the area of objectionable general economic proposals.

In view of industry's employee housing efforts a proposal favoring such an undertaking should not be frustrated by the bar against general social proposals. Yet a proposal that a real estate subdivision be opened up by a manufacturing company is palpably too general a social objective.

An example of a permissible specific religious proposal not outside the scope of the rule might be a proposal that a religious book company not purchase any raw materials from non-believers in God. Unduly general in the religious area is a proposal for requiring that all employees contribute a day's wages to a church of their choice.

While the omnibus "other similar causes" clause, like all omnibus clauses, is especially difficult to envision in terms of particular application, a possible type in this field is the patriotic proposal. A proposal that a furrier not buy any Russian furs, even though their market price and quality are attractive, seems adequately specific. A conceivable overly general proposal which might be offered as having a patriotic character, is one for adoption of the theme of opposition to creeping socialism in the company's magazine and newspaper advertising. However, if the management in its discretion has already embarked on such an advertising program, it would seem that a security holder should be permitted, if he de-

${ }^{150}$ See Exchange Act Réease No. 4668 (Jan. 31, 1952) and note 13 supra. 
sires, to propose that the program be superseded by a theme more closely related to the company's product or service. Perhaps the point of difference here is that the management to a considerable degree would appear to have resolved the question of the propriety of the subject matter by itself entering the field. If a different view were taken, the management could pass beyond the reach of the proposal rule and the security holder proponents. Similarly, the otherwise general nature of a proposal should not bar it if, not withstanding its generality, the action it contemplates is within the area of the particular company's own operation. In conclusion, it may well be questioned as to whether many proposals in the general areas described may not be ultra vires, and for that reason, if not on other grounds, not a proper subject.

\section{Conclusion}

There is no significant evidence of any abuse of the proposal rule. Unless one does not favor stockholder democracy, ${ }^{151}$ it is difficult to conceive any real objection to the present proposal rule or its administration. The failure of proposals to carry or win larger votes is no criterion by which to judge the proposal rule. The subject matter is competing ideas, and popularity affords no useful or enduring denominator of their relative or ultimate worth. ${ }^{152}$ The ideas contained in the proposals though controversial, far from being of the crack-pot variety, are at the least most stimulating, and, in fact, almost invariably had intrinsic substance. There is, therefore, no reason for immobilizing the gadfly. ${ }^{153}$ What is involved is basically the right of a minority to express itself and have an exchange of ideas-all in a business corporate context-but closely related to a fundamental freedom..$^{154}$

${ }^{151}$ Jackson Martindell, President of the American Institute of Management, in his Scientific Appraisal of Management (1950) states that "The corporation is not a democracy. The stockholder, lacking the power or the desire to control a company's operations, must accept management on faith." Ibid., at vii and 268. Such complete reliance upon faith is difficult to understand. While traditionally faith has had a place in man's thinking, it has, since the demise of the divine right of kings and the flowering of the Enlightenment, been reserved insofar as exclusive reliance is concerned to the deity rather than mere man, whether he be management or otherwise engaged. See as to the Enlightenment, Brinton, Ideas and Men 368-408 (1950).

152 Dennis v. United States, 341 U.S. 494, 503, 580 et seq. (1951).

${ }^{153}$ Cf. SEC Proxy Rules, Hearings before House Committee on Interstate and Foreign Commerce and H.R. 1493, H.R. 1821, H.R. 2019, 78th Cong. 1st Sess. (1943). It was charged at the time of these hearings that the then pending proposal rule would provide a "field day for crackpots." 165 Com. \& Fin. Chron. 2731 (May 22, 1947).

154 U.S. Const. Amend. 1. The writers wish to express their appreciation to the private individual previously referred to, see note 30 supra, Mr. Lewis D. Gilbert, and also to the companies who made available their proxy statements, their results of voting, and comments. 